\title{
Penerapan Pembelajaran Matematika ReAlistik UnTUK MENINGKATKAN KEMAMPUAN KOMUNIKASI MATEMATIS SISWA
}

\author{
Dwi Putria Nasution'1 and Marzuki Ahmad ${ }^{2 *}$ \\ 1Pendidikan Matematika, SMA Negeri 2 Padangsidimpuan \\ Jl. Merdeka No. 186, Padangsidimpuan, Sumatera Utara, Indonesia \\ putridwinst@gmail.com \\ ${ }^{2}$ Pendidikan Matematika, Institut Pendidikan Tapanuli Selatan \\ Jl. Stn. Mhd. Arif Kel. Batang Ayumi Jae, Padangsidimpuan, Sumatera Utara, Indonesia \\ Marzuki.ahmad45@yahoo.com
}

Artikel diterima: 31 Juli 2018, direvisi: 17 September 2018, diterbitkan: 30 September 2018

\begin{abstract}
Abstrak
Penelitian ini bertujuan untuk meningkatkan kemampuan komunikasi matematis siswa melalui pembelajaran matematika realistik. Metode penelitian yang digunakan adalah penelitian tidakan kelas yang meliputi tahap perencanaan, pelaksanaan, pengamatan dan refleksi. Subjek penelitian adalah siswa kelas VII-1 SMP Negeri 3 Padangsidimpuan dengan jumlah siswa 26 orang. Objek penelitian adalah kemampuan komunikasi matematis siswa yang diberi pembelajaran matematika realistik pada materi bilangan pecahan. Hasil penelitian menunjukkan bahwa penerapan pembelajaran matematika realistik memberikan dampak positif terhadap peningkatan kemampuan komunikasi matematis siswa yang ditunjukkan dengan peningkatan pada: 1) Nilai rata-rata kemampuan komunikasi matematis siswa 79,79 pada siklus I dan 84,71 pada siklus II; 2) Aktivitas aktif siswa dalam pembelajaran dengan pembelajaran matematika realistik dikategorikan efektif yakni memperoleh persentase $80 \%$ pada siklus I dan $90 \%$ efektif pada siklus dua dengan kriteria keefektifan $\geq 80 \%$; 3) Capaian ketuntasan kalasikal kemampuan komunikasi matematis siswa $73,08 \%$ pada siklus I dan $88,46 \%$ pada siklus II dengan nilai minimal ketuntasan klasikal 85\%.

Kata Kunci: Penerapan Pembelajaran, Matematika Realistik, Komunikasi Matematis
\end{abstract}

\begin{abstract}
The Aplication of Realistic Mathematics Educations to Improve students' mathematical communication Skills)

This study aims to improve students' mathematical communication skills through realistic mathematics education. The research method used is classroom action research which includes the stages of planning, implementation, observation and reflection. The research subjects were students of class VII-1 of SMP Negeri 3 Padangsidimpuan with a total of 26 students. The object of research is the mathematical communication skills of students who are given realistic mathematics education on fraction material. The results showed that the application of realistic mathematics education had a positive impact on the improvement of students 'mathematical communication skills as indicated by an increase in: 1) The average value of students' mathematical communication skills was 79.79 in cycle I and 84.71 in cycle II; 2) The active activity of students in learning with realistic mathematics learning is categorized as effective, namely obtaining $80 \%$ percentage in the first cycle and $90 \%$ effective in the second cycle with the effectiveness criteria $\geq 80 \%$; 3 ) Achievement of Kalasikal completeness of students' mathematical communication skills is $73.08 \%$ in cycle I and $88.46 \%$ in cycle II with a minimum grade of $85 \%$ classical completeness.

Keyword: Application of Learning, Realistic Mathematics, Mathematical Communication
\end{abstract}




\section{Pendahuluan}

Matematika merupakan subjek ideal yang mengembangkan kemampuan berpikir dan komunikasi anak mulai dari usia pendidikan dasar hingga pendidikan tinggi (Nasution, 2016). Kemampuan merupakan aspek penting dalam kemampuan bermatematika. Dengan adanya hasil pemikiran dalam bidang matematika tentu dapat disampaikan melalui komunikasi matematika. Permendiknas No. 22 tahun 2006 mengungkapkan salah satu tujuan pembelajaran matematika di jenjang pendidikan dasar dan menengah adalah mampu mengomunikasikan gagasan dengan simbol, tabel, diagram, atau media lain untuk memperjelas keadaan atau

Komunikasi secara umum dapat diartikan sebagai suatu peristiwa saling menyampaikan pesan yang berlangsung dalam suatu komunitas. Menurut Abdulhak (Ansari, 2012), "komunikasi dimaknai sebagai proses penyampaian pesan dari pengirim pesan kepada penerima pesan melalui saluran tertentu untuk tujuan tertentu". Komunikasi pemikiran dan menjelaskan pemahaman (Nopiyani dkk, 2018). Komunikasi matematika merupakan kemampuan menggunakan bahasa matematika untuk mengungkapkan gagasan matematik dan argumen dengan tepat, singkat dan masuk akal (Izzati dan Suryadi, 2010). Selanjutnya berpikir dan kemampuan komunikasi masalah. merupakan cara untuk berbagi hasil

Haji dan Abdullah (2016) menyatakan komunikasi matematis merupakan alat dalam pemecahan masalah, mencari solusi alternative pemecahan masalah, menginterpretasikan argumen, dan menggunakan pemecahan masalah matematik. Sehingga komunikasi matematika merupakan semua kegiatan yang meliputi pencatatan dan merepresentasikan ide-ide matematika dengan simbol atau bahasa matematika.

N.C.T.M. (2000) menjelaskan indikator kemampuan komunikasi matematis, yaitu: (a) Mengungkapkan ide matematika secara tertulis maupun lisan; (b) Merumuskan definisi dan membuat generalisasi; (c) Menyajikan matematika dengan pengertian; (d) Menjelaskan pertanyaan matematika; (e) Menghargai daya dan keindahan matematis. Selanjutnya Sumarmo (2014) kemampuan dalam komunikasi matematis adalah: 1) Menyatakan suatu masalah ke dalam bentuk bahasa, simbol, ide matematika; 2) Menjelaskan ide, situasi dan relasi matematika dalam bentuk bahasa biasa; 3) Mendengarkan, berdiskusi, dan menulis tentang matematika; 4) Memahami suatu representasi matematika; 5) Mengungkapkan kembali suatu uraian matematika dalam bahasa sendiri.

Kemampuan Komunikasi Matematis (KKM) merupakan kesanggupan siswa menyampaikan pesan matematika secara tertulis yang dapat diukur melalui: 1) Menginterpretasikan gambar ke dalam ide matematika; 2) Menyatakan ide-ide 
matematika dalam bentuk gambar; 3) Menyatakan ide matematika ke dalam pernyataan sendiri.

Ciri praktik pembelajaran di Indonesia selama ini adalah pembelajaran yang bersifat konvensional, dimana guru menjelaskan sementara siswa mendengar, mencatat dan mengerjakan soal latihan (Hadi, 2016). Pelaksanaan pembelajaran yang terjadi saat ini cenderung bersifat konvensional dan didominasi oleh aktivitas guru (Ahmad, 2016). Dominasi aktivitas guru dalam pembelajaran mengakibatkan menurunnya aktivitas siswa dalam pembelajaran yang berakibat pada rendahnya KKM siswa.

Observasi penelitian yang dilaksanakan di SMP Negeri 3 Padangsidimpuan pada tanggal 8 Agustus 2016 memberikan informasi bahwa pelaksanaan pembelajaran yang terjadi di kelas masih bersifat konvensional dan cenderung berpusat pada guru, aktivitas siswa dalam pembelajaran rendah dan KKM siswa rendah. Selanjutnya peneliti melakukan tes diagnostik pada siswa kelas VII-1 dengan memberikan tes KKM materi bilangan pecahan dalam bentuk soal essay tes sebanyak 5 soal. Tes yang dilaksanakan memberikan informasi bahwa perolehan nilai rata-rata KKM siswa 72,72 dan ketuntasan klasikal siswa rendah yaitu 57,69\%. Nilai ketuntasan klasikal tersebut masih jauh dari nilai minimal ketuntasan klasikal yang ditetapkan sekolah yaitu $85 \%$. Dengan demikian diperlukan adanya perbaikan proses kegiatan pembelajaran yang dapat meningkatkan KKM siswa.
Suatu pendekatan pembelajaran yang diawali dengan pemberian masalah kontekstual agar siswa aktif untuk menemukan dan merekonstruksi kembali konsep-konsep pelajaran matematika adalah Pembelajaran Matematika Realistik (PMR), Lestari \& Sofyan (2018). Pendekatan PMR memberi kesempatan kepada siswa untuk menemukan kembali (reinvention) konsep matematika seperti saat konsep tersebut ditemukan dengan bantuan dan bimbingan guru. Penemuan kembali dilakukan oleh siswa melalui pemecahan terhadap masalah realistik. Gravemeijer (1994) menyatakan bahwa PMR merupakan aktivitas manusia, yang dikembangkan dengan prinsip dasar, yaitu (1) Guided Reinvention and Progressive Mathematization (Penemuan terbimbing dan bermatematika secara progresif); (2) Didactical Phenomenology (Penomena dalam pembelajaran); dan (3) Selfdeveloped Models (Pengembangan model secara mandiri).

Sesuai dengan prinsip pembelajaran yang diuraikan sebelumnya, dalam kegiatan belajar mengajar dengan pendekatan PMR perlu memperhatikan karakteristik PMR. Menurut Treffers dalam Wijaya (2012) karakteristik PMR meliputi: 1) Penggunaan konteks yaitu pembelajaran matematika melibatkan siswa secara aktif untuk melakukan kegiatan eksplorasi permasalahan realistik yang merupakan titik awal; 2) Penggunaan model untuk mengembangkan matematisasi progressif yaitu siswa melakukan proses matematisasi yang 
http://journal.institutpendidikan.ac.id/index.php/mosharafa

meliputi penggunaan model of dan model for; 3) Pemanfaatan hasil konstruksi siswa yaitu siswa melakukan pengembangan terhadap strategi pemecahan masalah melalui proses konstruksi yang selanjutnya digunakan sebagai landasan pengembangan konsep matematika; 4) Terjadi interaktif guru dan siswa yaitu saling mengomunikasikan hasil kerja dan gagasan baik antara sesama siswa maupun antara siswa dengan guru; (5) Keterkaitan yaitu menggunakan keterkaitan materi-materi matematika yang bertujuan untuk membangun suatu konsep matematika yang baru.

Memperhatikan prinsip dan karakteristik PMR maka konteks (masalah dunia nyata) adalah sebagai titik awal untuk membangun suatu konsep pelajaran. Konteks diberikan dengan tujuan agar siswa menemukan kembali ide dan konsep matematika dengan bimbingan guru. Dengan adanya pemberian konteks, siswa akan menerjemahkan masalah dunia nyata ke dalam bentuk model matematika (matematisasi). Wijaya (2012) menyatakan matematisasi dalam PMR melibatkan generalisasi (generalizing) dan formalisasi (formalizing). Kedua aspek ini juga dikenal dengan matematisasi horizontal dan matematisasi vertikal yang pada akhir prosesnya diperoleh model formal matematika.

Pada proses pelaksanaan PMR terjadi interaktif guru dan siswa. interaktif yang terjadi meliputi interaksi antara siswa dengan siswa dan siswa dengan guru, 392
Ahmad \& Asmaidah (2018). Dengan adanya interaksi yang baik dalam pembelajaran akan meningkatkan aktivitas siswa yang pada akhirnya dapat meningkatkan KKM siswa. Adapun sintaks PMR yang diterapkan adalah memahami masalah kontekstual, menyelesaikan masalah kontekstual, membandingkan dan mendiskusikan jawaban, menyimpulkan atau menemukan pengetahuan. Dengan demikian penulis merasa penting untuk melakukan penelitian tentang penerapan PMR untuk meningkatkan KKM siswa melalui penelitian tindakan kelas.

\section{Metode}

Penelitian ini merupakan Penelitian Tindakan Kelas (PTK) yang bertujuan untuk meningkatkan Kemampuan Komunikasi Matematis (KKM) siswa melalui penerapan PMR. Tempat penelitian adalah SMP Negeri 3 Padangsidimpuan yang beralamat di Jl. K.H.A. Dahlan No.39 Padangsidimpuan Utara. Kota Pangsidimpuan Prov. Sumatera Utara Indonesia. Penelitian dilaksanakan pada bulan Agustus-Oktober tahun 2016 yaitu pada semester ganjil tahun ajaran 20162017. Adapun yang menjadi subjek penelitian adalah siswa kelas VII-1 SMP Negeri 3 Padangsidimpuan yaitu sebanyak 26 orang. Objek penelitian adalah KKM siswa yang diberi pembelajaran dengan pendekatan PMR.

Mekanisme penelitian dilaksanakan mengikuti tahapan PTK yang meliputi perencanaan, pelaksanan, observasi dan 
refleksi. Bagan tahapan PTK dapat dilihat pada gambar berikut.

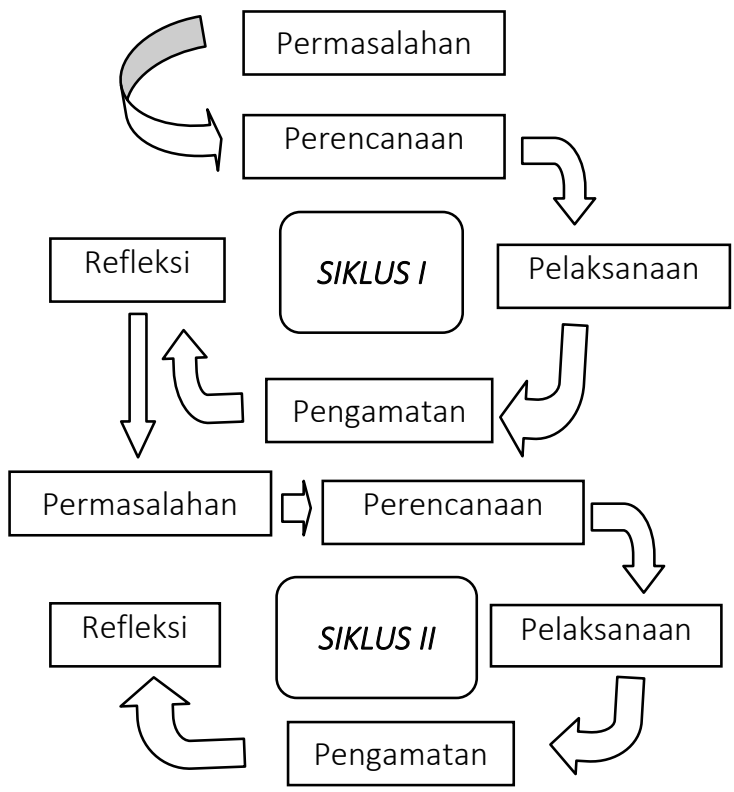

Gambar 1 Model PTK Menurut Kurt Lewin

(Rangkuti, 2016)

Tahapan penelitian dalam siklus I dan siklus II meliputi tahapan dalam PTK diuraikan sebagai berikut:

1. Tahap Perencanaan (planning) dilaksanakan wawancara terhapap guru guna mengetahui sekilas tentang model pembelajaran yang diterapkan, materi yang sedang dipelajari, serta kemampuan siswa dalam pembelajaran matematika. Selanjutnya disusun RPP, Lembar Aktivitas Siswa (LAS), lembar observasi, dan instrumen tes KKM.

2. Tahap Pelaksanaan (actions) dilakukan tindakan menerapkan PMR pada subjek penelitian sesuai dengan tahap perencanaan.

3. Tahap Observasi dilaksanakan melalui pengamatan dan tes. Pengamatan dilakukan terhadap aktivitas siswa dalam kegiatan pembelajaran sementara tes dilakukan setelah kegiatan pembelajaran terlaksana. Setelah data hasil observasi terkumpul, dilakukan analisis data. Tahap pengamatan tidak terlepas dari pelaksanaan tindakan, dimana pengamatan dilakukan ketika pelaksanaan kegiatan pembelajaran berlangsung (Rangkuti, 2016:210).

4. Tahap Refleksi yaitu kegiatan yang dilakukan dengan tujuan menganalisis apakah siklus berikutnya perlu dilakukan dengan membandingkan nilai capaian pembelajaran dengan ketuntasan klasikal yang ada pada sekolah.

Instrumen penelitian meliputi lembar observasi aktivitas siswa dan lembar tes KKM. Instrumen lembar observasi aktivitas siswa digunakan terhadap kelompok sampel terpilih untuk diamati dalam setiap pertemuan. Aktivitas siswa dalam kegiatan pembelajaran diamati selama kegiatan pembelajaran berlangsung dengan ketentuan empat menit untuk melakukan pengamatan dan satu menit dilakukan untuk pencatatan. Kegiatan (Aspek yang diamati) masing-masing mempunyai waktu ideal dan batas toleransi. Persentase pengamatan aktivitas siswa diperoleh melalui frekuensi rata-rata setiap aspek pengamatan dibagi dengan banyaknya frekuensi rata-rata semua aspek pengamatan dikali $100 \%$ dengan batas toleransi 5 \%, (Ahmad, 2016). Aktivitas siswa diamati, waktu ideal dan batas toleransi yang diterapkan dapat dilihat pada tabel berikut. 
http://journal.institutpendidikan.ac.id/index.php/mosharafa

Tabel 1.

Keterkaitan Kegiatan, Waktu Ideal dan Batas Toleransi Aktivitas KBM.

\begin{tabular}{|c|c|c|}
\hline $\begin{array}{c}\text { Kegiatan } \\
\text { (Aspek yang diamati) }\end{array}$ & $\begin{array}{c}\text { Waktu } \\
\text { Ideal }\end{array}$ & $\begin{array}{c}\text { Batas } \\
\text { Toleransi }\end{array}$ \\
\hline Membaca/memahami LAS & $15 \%$ & $5 \%$ \\
\hline $\begin{array}{l}\text { Memperhatikan penjelasan } \\
\text { guru }\end{array}$ & $10 \%$ & $5 \%$ \\
\hline Menyelesaikan masalah & $15 \%$ & $5 \%$ \\
\hline Mengajukan pertanyaan & $5 \%$ & $5 \%$ \\
\hline Diskusi antara siswa & $20 \%$ & $5 \%$ \\
\hline $\begin{array}{l}\text { Diskusi antara siswa dengan } \\
\text { guru }\end{array}$ & $5 \%$ & $5 \%$ \\
\hline $\begin{array}{l}\text { Memperagakan } \\
\text { hasil/menyampaikan ide }\end{array}$ & $15 \%$ & $5 \%$ \\
\hline $\begin{array}{l}\text { Mencatat hal-hal yang } \\
\text { relevan dengan kegiatan } \\
\text { pembelajaran }\end{array}$ & $5 \%$ & $5 \%$ \\
\hline Membuat kesimpulan & $5 \%$ & $5 \%$ \\
\hline $\begin{array}{l}\text { Portofolio (Menyelesaikan } \\
\text { PR dan hasil karya) }\end{array}$ & $5 \%$ & $5 \%$ \\
\hline
\end{tabular}

Instrumen tes penelitian yang digunakan adalah berupa tes KKM dalam bentuk essay sebanyak 5 soal dengan kisikisi sebagai berikut.

Tabel 2.

Kisi-kisi Tes KKM

\begin{tabular}{|c|c|c|}
\hline Indikator KKM & $\begin{array}{l}\text { Indikator Pencapaian } \\
\text { Tujuan Pembelajaran }\end{array}$ & $\begin{array}{l}\text { No. } \\
\text { Soal }\end{array}$ \\
\hline $\begin{array}{l}\text { Menginterpretasi } \\
\text { kan gambar ke } \\
\text { dalam ide } \\
\text { matematika }\end{array}$ & $\begin{array}{l}\text { Memahami sifat-sifat } \\
\text { operasi hitung bilangan } \\
\text { pecahan dan } \\
\text { penggunaannya dalam } \\
\text { pemecahan masalah. }\end{array}$ & 3 \\
\hline $\begin{array}{l}\text { Menyatakan ide- } \\
\text { ide matematika } \\
\text { dalam bentuk } \\
\text { gambar }\end{array}$ & $\begin{array}{l}\text { Memahami sifat-sifat } \\
\text { operasi hitung bilangan } \\
\text { pecahan dan } \\
\text { penggunaannya dalam } \\
\text { pemecahan masalah. }\end{array}$ & 1,4 \\
\hline $\begin{array}{l}\text { Menyatakan ide } \\
\text { matematika ke } \\
\text { dalam } \\
\text { pernyataan } \\
\text { sendiri. } \\
\end{array}$ & $\begin{array}{l}\text { Memahami sifat-sifat } \\
\text { operasi hitung bilangan } \\
\text { pecahan dan } \\
\text { penggunaannya dalam } \\
\text { pemecahan masalah. }\end{array}$ & 2,5 \\
\hline
\end{tabular}

Analisis data penelitian dilaksanakan dengan metode deskriptif. Data perolehan dari test KKM siswa dianalisis nilai capaiannya (NC) dan melakukan pengkategorian sesuai dengan proses pengkategorian yang ditetapkan disekolah yaitu: $90 \leq N C \leq 100$ baik sekali; 80 $\leq N C<89$ baik; $70 \leq N C<79$ cukup; 0 $\leq N C<69$ kurang. Penentuan keriteria ketuntasan KKM siswa disesuaikan dengan proses pengkategorian yang terdapat disekolah yaitu kriteria ketuntasan minimal siswa adalah nilai 80 dan kriteria ketuntasan klasikal kelas adalah $\geq 85 \%$.

\section{Hasil dan Pembahasan}

\section{A. Hasil Penelitian}

Penelitian yang dilaksanakan meliputi kegiatan siklus I dan siklus II yang temuan hasilnya dideskripsikan sebagai berikut.

1. Siklus I

Tahap perencanaan dilaksanakan dengan menyusun RPP, LAS, lembar observasi dan tes KKM siswa. Pembelajaran dirancang sebanyak tiga kali pertemuan. RPP disusun pada materi bilangan pecahan pada pokok bahasan: 1) Membandingkan dan mengurutkan pecahan; 2) Penjumlahan dan pengurangan bilangan pecahan; 3) Perkalian dan pembagian bilangan pecahan. Selanjutnya LAS disusun sesuai pokok bahasan yang akan dipelajari pada setiap pertemuan dengan rancangan yang menarik dan disertai dengan gambar yang sesuai dengan konteks permasalahan.

Lembar observasi disusun mengacu pada aktivitas siswa dalam kegiatan pembelajaran. Pengukuran tingkat efektivitas kegiatan dilakukan dengan mengamati kelompok sampel siswa dengan mencatat aktivitas dominan yang dilakukan siswa. Selanjutnya tes KKM dirancang sesuai dengan kisi-kisi yang 
melibatkan konteks yang dekat dengan kehidupan sehari-hari siswa yang masing masing soal didasarkan pada indikator dan penilaiannya mengacu pada rubrik penskoran KKM.

Tahap pelaksanaan dilakukan dengan menerapkan PMR sesuai dengan yang dirancang dalam tahap perencanaan. Pembelajaran dilaksanakan sebanyak tiga kali pertemuan yang masing-masing pertemuan dilakukan 80 menit terhadap subjek penelitian sebanyak 26 orang. Kegiatan pembelajaran melibatkan seorang pengamat yang bertujuan untuk mengamati aktivitas siswa pada kelompok sampel yang yang diamati dan seorang fotografer yang bertujuan untuk membuat dokumentasi kegiatan. Setelah kegiatan pembelajaran selama tiga kali pertemuan terlaksana maka siswa diberi tes KKM.

Tahap pengamatan meliputi kegiatan observasi yang dilakukan ketika pembelajaran berlangsung dan tes yang dilakukan setelah pembelajaran sebanyak tiga kali pertemuan terselesaikan. Hasil observasi dari tiga pertemuan dapat diamati pada tabel berikut.

Tabel 3.

Hasil Pengamatan Siklus I.

\begin{tabular}{|lc|}
\multicolumn{1}{c}{$\begin{array}{c}\text { Kegiatan } \\
\text { (Aspek yang diamati) }\end{array}$} & $\begin{array}{c}\text { Nilai Rata-rata Pert. } \\
1,2 \text { dan 3 }\end{array}$ \\
\hline Membaca/memahami LAS & $18.75 \%$ \\
\hline $\begin{array}{l}\text { Memperhatikan penjelasan } \\
\text { guru }\end{array}$ & $10.83 \%$ \\
\hline Menyelesaikan masalah & $13.33 \%$ \\
\hline Mengajukan pertanyaan & $5.83 \%$ \\
\hline Diskusi antara siswa & $13.33 \%$ \\
\hline $\begin{array}{l}\text { Diskusi antara siswa dengan } \\
\text { guru }\end{array}$ & $3.33 \%$ \\
\hline $\begin{array}{l}\text { Memperagakan } \\
\text { hasil/menyampaikan ide }\end{array}$ & $13.33 \%$ \\
\hline Mencatat hal-hal yang & $11.25 \%$ \\
\hline
\end{tabular}

Mosharafa: Jumal Pendidikan Matematika

Volume 7, Nomor 3, September 2018

Copyright @ 2018 Mosharafa: Jurnal Pendidikan Matematika

\begin{tabular}{ll}
\hline $\begin{array}{l}\text { relevan dengan kegiatan } \\
\text { pembelajaran }\end{array}$ \\
\hline Membuat kesimpulan & $4.17 \%$ \\
\hline $\begin{array}{l}\text { Portofolio (Menyelesaikan } \\
\text { PR dan hasil karya) }\end{array}$ & $5.83 \%$ \\
\hline
\end{tabular}

Melalui observasi yang dilakukan diperoleh bahwa data aktivitas siswa termasuk dalam kategori efektif dimana 8 aktivitas siswa yang diamati memenuhi batas toleransi waktu ideal atau $80 \%$ dari aktivitas yang diamati efektif. Selanjutnya berdasarkan tes yang dilakukan diperoleh nilai rata-rata tes KKM siswa sebesar 79,79 dan nilai persentase ketuntasan klasikal KKM siswa adalah 73,08\%. Interpretasi nilai siswa baik sekali sebanyak 4 siswa, baik 15 siswa, cukup 4 siswa dan kurang 3 siswa. Tabel perolehan nilai tes KKM siswa pada siklus I dapat diamati pada tabel berikut.

Tabel 4.

Perolehan Nilai Tes KKM Siklus I

\begin{tabular}{lccc}
\hline $\begin{array}{c}\text { Interpretasi Nilai } \\
\text { Siswa }\end{array}$ & Frekuensi & $\overline{\boldsymbol{X}}$ & $\begin{array}{c}\text { Ketun- } \\
\operatorname{tasan}(\%)\end{array}$ \\
\hline Baik Sekali & 4 & & \\
\cline { 1 - 2 } Baik & 15 & & \\
\hline Cukup & 4 & 73,08 & 79 \\
\cline { 1 - 2 } Kurang & 3 & & \\
\hline \multicolumn{1}{c}{ Jumlah } & 26 & & \\
\hline
\end{tabular}

Tahap Refleksi dalam siklus I dilakukan dengan membandingkan nilai ketuntasan klasikal yang diperoleh melalui tes dan nilai ketuntasan klasikal yang ditentukan sekolah yaitu sebesar $85 \%$. Dengan adanya kriteria ketuntasan minimal siswa sebesar 80 diperolehnya 19 siswa dari 26 siswa yang memenuhi atau melampaui kriteria ketuntasan minimal maka persentase kertuntasan klasikal KKM siswa 73,08\%. Capaian ketuntasan klasikal KKM siswa pada siklus I belum terpenuhi dimana harus dilaksanakan siklus selanjutnya 
(siklus II) untuk meningkatkan perolehan ketuntasan klasikal KKM siswa.

\section{Siklus II}

Tahap perencanaan pada siklus II dilaksanakan dengan menyusun RPP, LAS, lembar observasi untuk tiga kali pertemuan dan instrumen tes KKM siswa. RPP yang disusun masih pada materi dan pokok bahasan yang sama dengan siklus I. Perbaikan RPP dilakukan pada proses pembelajaran dengan mempertimbangkan kegiatan siswa dengan berpedoman pada hasil observasi pada siklus I. Hasil observasi kegiatan siswa terdapat 2 aspek yang tidak memenuhi batas toleransi yaitu yaitu diskuisi antara sesama siswa yang hanya sebesar 13,33\% dari batas toleransi ideal adalah 15\%-25\% dan mencatat halhal yang relevan adalah $11,25 \%$ dari batas toleransi 0\%-10\%.

Dari kondisi ini dilaksanakan revisi RPP dengan memberikan penekanan pada peningkatan terhadap aktivitas diskusi antara sesama siswa. Untuk mewujudkan hal tersebut dilaksanakan melalui memperbanyak kegiatan guru dalam scaffolding dan memberikan penjelasan kepada siswa dalam kegiatan pembelajaran. Selanjutnya diberikan informasi kepada guru agar lebih banyak dalam memberikan arahan dan bantuan pada kelompok belajar siswa dalam pemecahan masalah yang terdapat pada LAS.

Lembar observasi yang digunakan pada siklus II sama dengan lembar observasi yang digunakan pada siklus I. Selanjutnya instrumen tes yang dirancang dengan 396 memodivikasi butir soal tes KKM pada siklus I untuk dijadikan butir tes KKM pada siklus II. Butir soal tes KKM yang digunakan pada siklus II adalah butir soal yang setara tingkat kesulitannya dengan soal yang digunakan pada siklus I.

Tahap pelaksanaan dilakukan dengan menerapkan PMR sesuai dengan yang dirancang dalam tahap perencanaan siklus II. Pembelajaran dilaksanakan sebanyak tiga kali pertemuan yang masing-masing pertemuan dilakukan 80 menit terhadap subjek penelitian sebanyak 26 orang. Pelaksanaan pembelajaran pada siklus II dilaksanakan dengan mengikuti sintaks PMR namun pada fase memahami masalah kontekstual guru lebih banyak memberikan penjelasan melalui scaffolding pada kelompok belajar siswa dalam pembahasan LAS. Selanjutnya dalam proses menyelesaikan masalah kontekstual guru lebih memperhatikan siswa agar saling mendiskuisikan permasalahan yang terdapat pada LAS. Apabila siswa kurang kompak dalam diskuisi guru langsung memberikan anjuran agar pemecahan permasalahan LAS agar senantiasa didiskuisikan secara bersama-sama dalam kelompok masingmasing.

Tahap pengamatan meliputi kegiatan observasi yang dilakukan ketika pembelajaran berlangsung dalam tiga kali pertemuan. Observasi dilakukan terhadap satu kelompok terpilih dalam setiap pertemuan pembelajaran dilaksanakan. Adapun rata-rata hasil observasi dalam

Mosharafa: Jumal Pendidikan Matematika Volume 7, Nomor 3, September 2018 Copyright $\odot 2018$ Mosharafa: Jurnal Pendidikan Matematika 
pertemuan 1,2,3 pada siklus dua dapat diamati pada tabel berikut.

Tabel 5. Hasil Pengamatan Siklus II.

\begin{tabular}{|lc|}
\hline \multicolumn{1}{c}{ (Aspek yang diamati) } & $\begin{array}{c}\text { Nilai Rata-rata Pert. } \\
\mathbf{1 , 2} \text { dan 3 }\end{array}$ \\
\hline Membaca/memahami LAS & $15.83 \%$ \\
\hline $\begin{array}{l}\text { Memperhatikan penjelasan } \\
\text { guru }\end{array}$ & $11.67 \%$ \\
\hline Menyelesaikan masalah & $15.00 \%$ \\
\hline Mengajukan pertanyaan & $5.00 \%$ \\
\hline Diskusi antara siswa & $16.25 \%$ \\
\hline $\begin{array}{l}\text { Diskusi antara siswa dengan } \\
\text { guru }\end{array}$ & $2.50 \%$ \\
\hline $\begin{array}{l}\text { Memperagakan } \\
\text { hasil/menyampaikan ide }\end{array}$ & $12.92 \%$ \\
\hline $\begin{array}{l}\text { Mencatat hal-hal yang } \\
\text { relevan dengan kegiatan } \\
\text { pembelajaran }\end{array}$ & $10.42 \%$ \\
\hline Membuat kesimpulan & $3.75 \%$ \\
\hline $\begin{array}{l}\text { Portofolio (Menyelesaikan } \\
\text { PR dan hasil karya) }\end{array}$ & $6.67 \%$ \\
\hline
\end{tabular}

Melalui observasi yang dilakukan terdapat satu aktivitas yang tidak memenuhi batas toleransi yaitu mencatat hal-hal yang relevan dalam pembelajaran yaitu terlalu tinggi. Persentasi aktivitas yang diperoleh $10,42 \%$ dari batas toleransi 0\%-10\%. Namun bila dikaitkan dengan kriteria keefektifan adalah mesti diperoleh aktivitas yang memenuhi batas toleransi keefektifan yaitu sebesar $80 \%$ maka data aktivitas siswa termasuk dalam kategori efektif dimana 9 aktivitas siswa yang diamati memenuhi batas toleransi waktu ideal atau 90\% dari aktivitas yang diamati efektif. Selanjutnya dilakukan tes KKM pada siklus II yang dilakukan diperoleh nilai rata-rata tes KKM siswa sebesar 84,71 dan nilai persentase ketuntasan klasikal KKM siswa adalah 88,46\%. Interpretasi nilai siswa baik sekali sebanyak 10 siswa, baik 13 siswa, cukup 2 siswa dan kurang 1 siswa. Tabel perolehan nilai tes KKM siswa pada siklus II dapat diamati pada tabel berikut.

Tabel 6.

Perolehan Nilai Tes KKM Siklus II

\begin{tabular}{lccc}
\hline $\begin{array}{c}\text { Interpretasi } \\
\text { Nilai Siswa }\end{array}$ & Frekuensi & $\overline{\boldsymbol{X}}$ & $\begin{array}{c}\text { Ketun- } \\
\operatorname{tasan}(\%)\end{array}$ \\
\hline Baik Sekali & 10 & & \\
\cline { 1 - 2 } Baik & 13 & & \\
\cline { 1 - 2 } Cukup & 2 & & 88,46 \\
\cline { 1 - 2 } Kurang & 1 & & \\
\hline \multicolumn{1}{c}{ Jumlah } & 26 & & \\
\hline
\end{tabular}

Tahap Refleksi dalam siklus II dilakukan dengan membandingkan nilai ketuntasan klasikal yang diperoleh melalui tes dan nilai ketuntasan klasikal yang ditentukan sekolah. Dengan diperolehnya 23 dari 26 siswa yang memenuhi kriteria ketuntasan minimal yang ditetapkan sekolah maka persentase ketuntasan klasikal KKM siswa sebesar 88,46\%. Nilai tersebut telah melewati batas minimal ketuntasan klasikal (85\%) yang ditetapkan sekolah maka penerapan PMR dalam meningkatkan KKM siswa telah terpenuhi.

\section{B. Pembahasan}

Kemampuan komunikasi matematis merupakan kesanggupan dalam menyampaikan pesan matematika secara tertulis. KKM diukur melalui indikator menginterpretasikan gambar ke dalam ide matematika, menyatakan ide-ide matematika dalam bentuk gambar, menyatakan ide matematika ke dalam pernyataan sendiri.

Kemampuan menginterpretasikan gambar ke dalam ide matematika terbentuk dalam memahami 
permasalahan yang ditampilkan. Dimana siswa melalui kelompok saling memberi tanggapan dalam menginterpretasikan gambar yang pada akhirnya gambar dapat diinterpreatasikan. Kemampuan menyatakan ide-ide matematika dalam bentuk gambar ini terbentuk melalui scaffolding yang diberikan guru dan diskuisi antara sesama siswa. Proses scaffolding yang dilakukan guru terhadap siswa dapat membuat siswa memahami ide yang ada dan dapat mengilustrasikannya kedalam bentuk gambar. Selanjutnya kemampuan menyatakan ide matematika ke dalam pernyataan sendiri terbentuk ketika siswa siswa membandingkan dan mendiskuisikan jawaban. Dimana melalui ungkapan pernyataan yang disampaikan suatu kelompok yang tidak sependapat dengan kelompok yang lain akan terjadi saling bertukar pengetahuan yang dapat memperkaya pernyataan ide matematika yang ada.

KKM siswa pada tes siklus I diperoleh ketuntasan klasikal sebesar 73,08\%. Karena persentase ketuntasan klasikal yang diperoleh belum memenuhi ketuntasan klasikal yang ditetapkan sekolah maka dilanjutkan ke siklus II dengan perolehan ketuntasan klasikal $88,46 \%$. Dengan diperolehnya ketuntasan $>85 \%$ pada siklus II maka peningkatan siswa melalui pembelajaran matematika realistik terpenuhi.

\section{Penutup}

Adapun kesimpulan yang diperoleh dari hasil dan pembahasan penelitian adalah penerapan PMR dalam meningkatkan KKM siswa memiliki dampak positif dalam proses pembelajaran yang ditandai dengan meningkatnya ketuntasan klasikal dan nilai rata-rata siswa dalam setiap siklus yang dilakukan. Ketuntasan klasikal siswa pada siklus I yaitu $73,08 \%$ dan siklus II 88,46\%. Nilai ketuntasan klasikal pada siklus 2 telah memenuhi ketuntasan klasikal yang ditentukan dimana nilai yang diperoleh telah melebihi nilai ketuntasan klasikal $85 \%$. Selanjutnya nilai rata-rata KKM siswa secara beruturut-turut meningkat yaitu siklus I sebesar 79,79 kemudian siklus || sebesar 84,71. Sehingga penerapan PMR pada pokok bahasan bilangan pecahan dapat meningkatkan KKM siswa SMP Negeri 3 Padangsidimpuan tahun ajaran 2016-2017.

Adapun saran dari peneliti sehubungan dengan penelitian yang telah dilakukan adalah sebagai berikut: 1 ) Penerapan PMR pada pembelajaran matematika yang menekankan pada KKM siswa dapat dijadikan sebagai salah satu alternatif untuk menerapkan pembelajaran matematika yang inovatif; 2) Sebaiknya siswa dibelajarkan dengan pembelajaran yang yang merangsang aktivitas aktif siswa sehingga siswa dapat lebih kreatif dan dapat menemukan sendiri konsep, prinsip dan makna materi yang dipelajari dengan guru hanya berperan sebagai fasilitator; 3) Kepada 
peneliti berikutnya hendaknya dapat dilengkapi dengan meneliti aspek kemampuan matematis lainnya yang belum terjangkau pada penelitian ini.

\section{UCAPAN TERIMA KASIH}

Peneliti mengucapkan terima kasih kepada pimpinan dan pengurus SMP Negeri 3 Padangsidimpuan. Dimana pihak sekolah yang meliputi kepala sekolah, guru mata pelajaran matematika dan petugas administrasi telah mendukung dan memberikan kesempatan kepada penulis untuk melaksanakan penelitian di sekolah tersebut pada tahun 2016.

\section{Daftar Pustaka}

Ahmad, M. (2016). Aktivitas Aktif Siswa dalam Pembelajaran Matematika Realistik.Jurnal Education and Development, 2(5), 45-45.

Ahmad, M., \& Asmaidah, S. (2018). Pengembangan

Perangkat

Pembelajaran Matematika Realistik untuk Membelajarkan Kemampuan Pemecahan Masalah Matematika Siswa SMP.Mosharafa: Jurnal Pendidikan Matematika,6(3), 373384.

Ansari, B. (2012). Komunikasi Matematik dan Politik Suatu Perbandingan: Konsep dan Aplikasi. Banda Aceh: Yayasan PeNA.

Gravemeijer, K.P.E. (1994). Developing Realistic Mathematics Education. Utrecht, Nederlands: Freudenthal Institute.
Hadi, S. (2016). Pendidikan Matematika Realistik Teori, Pengembangan dan Implementasinya. Jakarta: Rajawali Pers.

Haji, S., \& Abdullah, M. I. (2016). Peningkatan Kemampuan Komunikasi Matematik Melalui Pembelajaran Matematika Realistik. Infinity Journal, 5(1), 42-49. Sumber: http://ejournal.stkipsiliwangi.ac.id/index.php/i nfinity/article/view/190/165

Izzati, N., \& Suryadi, D. (2010, November). Komunikasi matematik dan pendidikan matematika realistik. In Prosiding Seminar Nasional Matematika dan Pendidikan Matematika, Yogyakarta, UNY(Vol. 27, pp. 721-729). Sumber: http://ejournal.stkipsiliwangi.ac.id/index.php/i nfinity/article/view/190/165

Lestari, L., \& Sofyan, D. (2018). Perbandingan Kemampuan Pemecahan Masalah Siswa dalam Matematika antara yang Mendapat Pembelajaran Matematika Realistik (PMR) dengan Pembelajaran Konvensional. Mosharafa: Jurnal Pendidikan Matematika, 3(2), 95-108. Sumber:https://journal.institutpendidi kan.ac.id/index.php/mosharafa/article /view/mv3n2 4/235

Nasution, D. P. (2017). Peningkatan Kemampuan Komunikasi dan Selfefficacy Matematis Siswa melalui Pendekatan Realistik di SMP N 4 Padangsidimpuan. Jurnal Mathematic Paedagogic, 2(1), 45-54. 
N. C. T. M. (2000). Principles and standards for school mathematics. Reston, VA: The National Council of Teachers of Mathematics.

Nopiyani, D., Turmudi, T., \& Prabawanto, S. (2018). Penerapan pembelajaran matematika realistik berbantuan geogebra untuk meningkatkan kemampuan komunikasi matematis siswa SMP. Mosharafa: Jurnal Pendidikan Matematika, 5(2), 45-52. Sumber:

https://journal.institutpendidikan.ac.i d/index.php/mosharafa/article/view/ mv5n2 $1 / 264$

Permendiknas. (2006). Peraturan Menteri Pendidikan Nasional No. 22 tentang Standar Isi.

Rangkuti, N.A. (2016). Metode penelitian pendidikan pendekatan kuantitatif, Kualitatif, PTK dan Penelitian Pengembangan. Bandung: Cipta Pustaka Mulia.

Sumarmo, U. (2014). Pengembangan Hard Skill dan Soft Skill Matematik Bagi Guru dan Siswa untuk Mendukung Implementasi Kurikulum 2013. In Prosiding Seminar Nasional Pendidikan Matematika Program Pasca Sarjana (pp. 4-15). Sumber: http://publikasi.stkipsiliwangi.ac.id/fil es/2014/01/Prosiding-15-Januari2014.pdf

Wijaya, A. (2012). Pendidikan Matematika Realistik, Suatu Alternatif Pendekatan Pembelajaran

Matematika. Yogyakarta: Graha Ilmu.

\section{Riwayat HidUP PENULIS}

Dwi Putria Nasution, S.Pd, M.Pd.

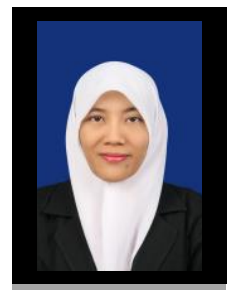

Lahir di Padangsidimpuan, 13 Mei 1988. Staf pengajar di SMA Negeri 2 Padangsidimpuan. Studi S1 Pendidikan Matematika STKIP Tapanuli Selatan, Padangsidimpuan, lulus tahun 2010; S2 Pendidikan Matematika UNIMED, Medan, lulus tahun 2016.

Marzuki Ahmad, S.Pd, M.Pd.

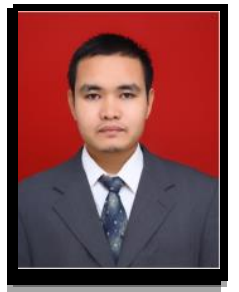

Lahir di Laru Lombang, 18 September 1988. Staf pengajar di Institut Pendidikan Tapanuli Selatan. Studi S1 Pendidikan Matematika Universitas Islam Sumatera Utara, Medan, dan lulus tahun 2010; dan studi S2 Pendidikan Matematika Universitas Negeri Medan (Unimed) dan lulus tahun 2014. 